\title{
Utilizando a ludicidade para ensino interdisciplinar em sala de aula
}

\author{
Murillo Pires de Sá1; Jéssica Paula Jacinto de Oliveira²; Daniela \\ Borges de Lima33; Geraldo Sadoyama Leal4; Adriana Santos P. \\ Sadoyama5; Paulo Alexandre de Castro6; Leonardo Santos Andrade ${ }^{7}$
}

\section{Resumo}

O uso do lúdico em sala de aula se relaciona ao desenvolvimento de brincadeiras, jogos e atividades com a função educativa, oportunizando a aprendizagem do indivíduo de forma agradável gerando interesse por parte dos alunos. Nesse sentido, este estudo tem como objetivo demonstrar o uso de atividade lúdica em sala de aula, através de perguntas e respostas interdisciplinares, utilizando um jogo inspirado na "batata quente" convencional. Os alunos foram dispostos em círculo voltados para o centro no primeiro momento, e voltados para fora em um segundo momento. Uma bola era passada de mão em mão enquanto uma música tocava ao fundo. Quando a música parava o aluno que estivesse com a bola em mãos deveria sortear uma pergunta de múltipla escolha, entre um total de quarenta, as

${ }^{1}$ Graduando do curso de Licenciatura em Ciências Biológicas, Universidade Federal de Goiás, Regional Catalão (UFG/RC). Catalão - GO, Brasil, E-mail: murillopires@msn.com

2 Graduando do Curso de Licenciatura em Pedagogia, Universidade Federal de Goiás, Regional Catalão (UFG/RC). Catalão - GO, Brasil, E-mail: jessicagodinha2011@ hotmail.com

3 Docente supervisor PIBID subprojeto Interdisciplinar, Universidade Federal de Goiás, Regional Catalão (UFG/RC). Catalão - GO, Brasil, E-mail: danielaborgeslima1 @ gmail.com

4 Coordenador de Área do Subprojeto Interdisciplinar - (PIBID, UFG/RC), E-mail: gsadoyama@gmail.com

5 Coordenadora de Área do Subprojeto Interdisciplinar - (PIBID, UFG/RC), E-mail: drisadoyama@gmail.com

${ }^{6}$ Coordenador de Área do Subprojeto Interdisciplinar - (PIBID, UFG/RC), E-mail: padecastro@ufg.br

7 Coordenador de Área do Subprojeto Interdisciplinar - (PIBID, UFG/RC), E-mail: 1s_andrade@yahoo.com.br 
quais foram selecionadas especificadamente para a aplicação dessa atividade. As perguntas possuíam caráter interdisciplinar, abrangendo várias áreas do conhecimento e estabelecendo as relações existentes entre as disciplinas. A cada acerto gerava-se um brinde de forma a reforçar positivamente. Já os erros eram corrigidos pelo próprio aluno após ser estimulado e auxiliado a alcançar a resposta correta. A avaliação ocorreu de forma dinâmica com o intuito de verificar o desempenho dos alunos durante a atividade proposta e aplicar o lúdico como forma de ensino de maneira divertida, diferente do convencional que por muitas vezes não é bem recebida por parte dos alunos. Após a atividade os alunos descreveram o que conseguiram aprender com o jogo proposto, também relataram a importância da ludicidade para gerar o interesse deles no conteúdo. Com a utilização desta metodologia foi possível alcançar a sala de aula de maneira atrativa promovendo a participação de todos os alunos alcançando o objetivo proposto e auxiliando no processo de ensino-aprendizagem. Apoio: PIBID/CAPES

Palavras Chave: Lúdico; Interdisciplinar; Ensino. 